\title{
DNA Measurement and Cell Cycle Analysis by Flow Cytometry
}

\author{
Rafael Nunez* \\ Associate Laboratory Member, Memorial Sloan-Kettering \\ Cancer Center, Box 98, 1275 York Avenue, New York, \\ NY 10021, USA
}

\begin{abstract}
Measurement of cellular DNA content and the analysis of the cell cycle can be performed by flow cytometry. Protocols for DNA measurement have been developed including Bivariate cytokeratin/DNA analysis, Bivariate BrdU/DNA analysis, and multiparameter flow cytometry measurement of cellular DNA content. This review summarises the methods for measurement of cellular DNA and analysis of the cell cycle and discusses the commercial software available for these purposes.
\end{abstract}

\section{Introduction}

Two of the most popular flow cytometric applications are the measurement of cellular DNA content and the analysis of the cell cycle. Therefore, diverse protocols for DNA measurement have been developed including Bivariate cytokeratin/DNA analysis, Bivariate BrdU/DNA analysis, and multiparameter flow cytometry measurement of cellular DNA content. These analyses have been paralleled with the development of commercial software for cell cycle analysis.

\section{Flow Cytometry Measurement of Cellular DNA Content}

The nuclear DNA content of a cell can be quantitatively measured at high speed by flow cytometry. Initially, a fluorescent dye that binds stoichiometrically to the DNA is added to a suspension of permeabilized single cells or nuclei. The principle is that the stained material has incorporated an amount of dye proportional to the amount of DNA. The stained material is then measured in the flow cytometer and the emitted fluorescent signal yields an electronic pulse with a height (amplitude) proportional to the total fluorescence emission from the cell. Thereafter, such fluorescence data are considered a measurement of the cellular DNA content. Samples should be analyzed at rates below 1000 cells per second in order to yield a good signal of discrimination between singlets or doublets.

Since the data obtained is not a direct measure of cellular DNA content, reference cells with various amounts of DNA should be included in order to identify the position

*For correspondence. Email nunezr@mskcc.org;

Tel. (212) 639-6392; Fax. (917) 432-2333. of the cells with the normal diploid amount of DNA. Some of the common reference cells often used for DNA measurements are human leukocytes or red blood cells from chicken and trout (Figure 1).

Commonly DNA measurements are expressed as a DNA index of the ratio of sample DNA peak channel to reference DNA peak channel. A DNA index of 1.0 represents a normal diploid DNA content, while deviations in cellular DNA content values other than 1.0 indicate DNA aneuploidy.

\section{The Analysis of the Cell Cycle}

In addition to determining the relative cellular DNA content, flow cytometry also enables the identification of the cell distribution during the various phases of the cell cycle. Four distinct phases could be recognized in a proliferating cell population: the G1-, S- (DNA synthesis phase), G2- and M-phase (mitosis). However, G2- and M-phase, which both have an identical DNA content could not be discriminated based on their differences in DNA content (Figures 1 and 2). Diverse software containing mathematical models that fit the DNA histogram of a singlet have been developed in order to calculate the percentages of cells occupying the different phases of the cell cycle.

\section{Approach to Discriminate Doublets or Cellular Aggregates}

A common feature of DNA analysis is the finding of doublets or cellular aggregates. A doublet is formed when two cells with a G1-phase DNA content are recorded by the flow cytometer as one event with a cellular DNA content similar to a G2/M-phase cell. If a sample contains many doublets, that could mistakenly increase the relative number of cells in the G2/M-phase of the cell cycle, yielding to an overestimation of G2/M population. In order to correct this error, modern flow cytometers are equipped with a Doublet Discrimination Module that selects single cells on the basis of pulse processed data. The emitted fluorescent light of the DNA dye (FL2) generates an electronic signal that can be recorded as high (FL2H) for the intensity of the staining as well as measured as pulse-area (FL2A) and pulse-width (FL2W) of the samples. By plotting the FL2W versus FL2A in a dot plot graph a discrimination of a G1 doublet from a $\mathrm{G} 2 / \mathrm{M}$ single can be made. Since the FL2W increases with the diameter of the doublet particle while both the $\mathrm{G} 1$ doublet and the G2/M single produce a same FL2A signal is likely to discriminate the doublet from the single (Figure 1). Therefore, in the dot plot graph a gate (G0/G1/S/G2/M) is set around the single population. The histogram graph of this gated population shows the four distinct phases that could be recognized in a proliferating cell population (Figure 2, upper right panel): the G0/G1-, S- (DNA synthesis phase), G2- and M-phase (mitosis). The number of cells 


\section{DNA.004}

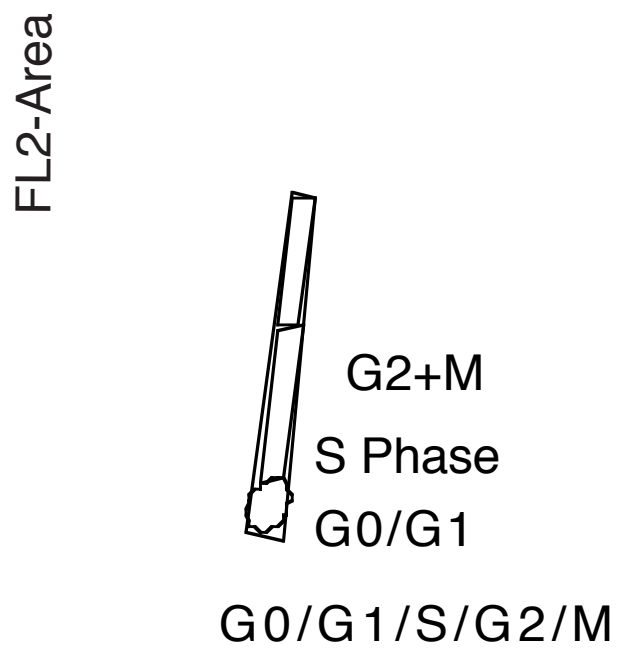

\section{FL2-Width}

Figure 1. Dot plot of FL2W/FL2A for DNA content and doublet discrimination. An example of doublet discrimination in a dot plot of FL2W/FL2A. The G0/G1/ S/G2/M population is gated.

in each phase is shown in Figure 1. G0/G1 is in lower left panel; $S$ phase is in lower middle panel and G2/M in lower right panel.

\section{Software for Cell Cycle Analysis}

Diverse manufacturers such as Becton Dickinson have developed software (CellFit ${ }^{\mathrm{TM}}$ ) for cell cycle analysis. The diverse software provides several mathematical models for fitting the DNA histogram. However, a subtraction of the background is required in order to remove events due to debris and to get a better fit with the models. Before the actual calculation of the phase distributions, two regions that are marked at the left and at the right part of the histogram are examined. Then, the data are fitted into an exponential curve of the form $y=e^{(a x+b)}$, and then the portion of the histogram that includes the two regions is subtracted from this curve. CellFit uses this approach to subtract the background.

However when using modeling for cell cycle statistics, there is a lot of variability and a factor of error because minute variation in the sampling and preparative techniques of the cells can contribute to inaccurate estimates. Therefore, it is essential to be aware of that variability in the analysis and interpretation of DNA content histograms. Also, it is important to evaluate the advantages of each software package and their respective limitations before using one for the analysis and fitting in the cell cycle models.

\section{Bivariate BrdU/DNA}

Flow cytometric analysis of cell DNA content is widely used for the estimation of cell cycle phase distributions. However, this analysis does not provide cytodynamic information such as cycle traverse rates and phase transit times. These parameters can be obtained using autoradiographic 


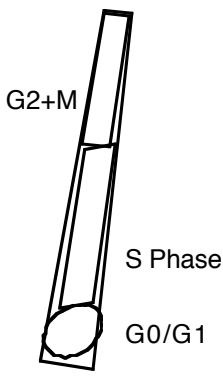

G0/G1/S/G2/M

Figure 2. DNA and cell cycle analysis. An example of DNA and cell cycle analysis. Upper left panel shows the dot plot of FL2W/FL2A. The Go/G1/S/G2/M population is gated. Upper right panel shows the histogram of the gated G0/G1/S/G2/M cells: the G0/G1-, S- (DNA synthesis phase), G2- and M-phase (mitosis). The number of cells in each phase is shown in Figure 1 lower panels. G0/G1 is in lower left panel; S phase is in lower middle panel and G2/M in lower right panel.

techniques, in particular, by determining the fraction of labeled mitosis. By autoradiographic identification of labeled cells during various intervals after labeling, their transition through the subsequent mitotic divisions can be followed, and phase and cycle transit times can be calculated.

In the last few years, non autoautoradiographic methods for distinguishing DNA synthesizing cells have been developed. These use monoclonal antibodies to measure the incorporation of bromodeoxyuridine (BrdUrd) into cellular DNA. In an indirect immunocytochemical technique, cells, which have incorporated BrdUrd, can be labeled with a fluorochrome and simultaneously the DNA can be counterstained. Flow cytometry then allows the simultaneous measurement of incorporated BrdUrd as well as the DNA content on a single cell level. In this way the cohort of labeled cells can be followed through the cell cycle.

\section{DNA Content Analysis}

In addition to analysis of cellular DNA content in lymphoreticular and hematopoietic neoplasm, flow cytometry has been used to characterize solid tumors. The most frequent tissues analyzed are a) biopsies from breast tumors, and b) tissue derived from products of conception. However, the value of DNA content analysis as a prognostic indicator in the case of tumors has been rather inconsistent and its use is being restricted to specific entities like breast cancer.

Staining is with a nucleic acid dye like propidium iodide (PI) and is similar to that described so far for other DNA assays. However, there are several circumstances in the staining procedures and analysis that require careful attention in order to avoid false interpretations. For example, since RNA would interfere in the staining, the solution should also contain RNAase. Also the number of cells acquired are critical in order to ensure that adequate 
cell numbers are collected. In addition, non-specific lowlevel staining must be excluded and only strongly stained cells should be collected in order to perform an accurate modeling of the data. Also as a part of the analysis, it is important to exclude debris and aggregates, as they will interfere with the measurements. Moreover, in some other circumstances, the G0/G1 peak of one ploidy distribution may be localized in the same area as the S-phase component of another distribution. In those circumstances when there is more than one ploidy distribution it is almost impossible by drawing a few analysis regions to delineate the cell cycle compartments. Therefore, the analysis and quantification of cell cycle compartments is a pretty complex task that requires the use of software for modeling.

\section{Example of a Typical Analysis}

Stained sample is collected on the cytometer and displayed for qualitative assessment. The gating strategy varies depending of the type of software but always includes a step to exclude aggregates. Thereafter, FL2W and FL2A are plotted as either dot plot or contour plot. A gate is set up in the area of cells with 2N DNA content. Moreover, there still exists the possibility that one of the cells containing 4N DNA content could be located inside the single gate, or that doublets with 2N DNA content will be located outside the gate. A one-parameter histogram of FL2-A (PI fluorescence) is drawn from the cells with $2 \mathrm{~N}$ DNA content. Usually two major peaks are observed; one peak is labeled as diploid and included in the region $\mathrm{R} 1$ that is colored in red and the other peak is labeled as aneuploid and included in the region $\mathrm{R} 2$ that is colored in green. In the further analysis, R1 is always depicted in red and R2 is depicted in green and any cells not associated with these two regions appear white. A SSC/FL2 dot plot is drawn which shows that the debris was stained neither in red nor in green but in white, facilitating its subtraction out of the analysis.

The report shows the separation and quantification of the two ploidy distributions: diploid and aneuploid, as well as the calculation of the cell percentages in each cycle compartment. Also it shows the CV's for the Go/G1 peak of each distribution, and a measurement of the DNA Index (DI), which is the aneuploid/euploid DNA content ratio.

\section{References}

Ross, J.S. 1996. DNA Content analysis. In: DNA Ploidy and Cell Cycle Analysis in Pathology. Igaku-Shoin, NY.

Bagwell, C.B. 1993. Theoretical aspects of data analysis. In: Clinical Flow Cytometry Principles and Application. Ed Bauer KD, Duque RE and Shankey TV. p. 41-61.

Rabinovitch, P.S. 1993. DNA analysis guidelines. In: Practical Considerations for DNA Content and Cell Cycle Analysis. Ed Bauer KD, Duque RE and Shankey TV. p. 117-142.

Bauer, K.D., et al. 1993. Cell cycle antigens. In: Guidelines for Implementation of Clinical DNA Cytometry. Vol. 14, No. 5. p. 472-477.

Bauer, K.B., and Jacobberger, J.W. 1994. Analysis of intracellular proteins. In: Methods in Cell Biology: Flow
Cytometry Vol 41, 2nd edition, eds. Z. Darzynkiewicz, H. A. Crissman, J. P. Robinson, Academic Press, Inc., NY, pp351-376.

Srivastava, P., Sladek, T.L., Goodman, M.N., and Jacobberger, J.W. 1992. Streptavidin-based quantitative staining of intracellular antigens for flow cytometric analysis. Cytometry. 13: 711-720.

Sladek, T.L., and Jacobberger, J.W. 1992. Dependence of SV40 large T-antigen cell cycle regulation on T-antigen expression levels. Oncogene. 7: 1305-1313.

Sladek, T.L., and Jacobberger, J.W. 1993. Flow cytometric titration of retroviral expression vectors: Comparison of methods for analysis of immunofluorescence histograms derived from cells expressing low antigen levels. Cytometry. 14: 23-31.

Sladek, T.L., and Jacobberger, J.W. 1998. Cell cycle analysis of retroviral vector gene expression during early infection. Cytometry. 31: 235-241.

Sramkoski, R.M., Wormsley, S.W., Bolton, W.E., Crumpler, D.C., Jacobberger, J.W. 1999. Simultaneous detection of cyclin B1, p105, and DNA content provides complete cell cycle phase fraction analysis of cells that endoreduplicate. Cytometry. 35: 274-283.

Jacobberger, J.W., Sramkoski, R.M., Wormsley, S.B., Bolton, W.E. 1999. Estimation of cell cycle-related gene expression in $\mathrm{G} 1$ and $\mathrm{G} 2$ phases from immunofluorescence flow cytometry data. Cytometry. 35: 284-289.

Hedley, D.W., et al. 1999. Consensus review of the clinical utility of DNA cytometry in carcinoma of the breast. Cytometry. 14: 482-485.

Hedley, D.W. 1993. Breast Cancer. Ed Bauer KD, Duque RE and Shankey TV. p. 247-261. 


\section{Further Reading}

Caister Academic Press is a leading academic publisher of advanced texts in microbiology, molecular biology and medical research. Full details of all our publications at caister.com

- MALDI-TOF Mass Spectrometry in Microbiology Edited by: M Kostrzewa, S Schubert (2016) www.caister.com/malditof

- Aspergillus and Penicillium in the Post-genomic Era Edited by: RP Vries, IB Gelber, MR Andersen (2016) www.caister.com/aspergillus2

- The Bacteriocins: Current Knowledge and Future Prospects Edited by: RL Dorit, SM Roy, MA Riley (2016)

www.caister.com/bacteriocins

- Omics in Plant Disease Resistance Edited by: V Bhadauria (2016) www.caister.com/opd

- Acidophiles: Life in Extremely Acidic Environments Edited by: R Quatrini, DB Johnson (2016) www.caister.com/acidophiles

- Climate Change and Microbial Ecology: Current Research and Future Trend

Edited by: J Marxsen (2016)

www.caister.com/climate

- Biofilms in Bioremediation: Current Research and Emerging Technologies

Edited by: G Lear (2016)

www.caister.com/biorem

- Microalgae: Current Research and Applications Edited by: MN Tsaloglou (2016) www.caister.com/microalgae

- Gas Plasma Sterilization in Microbiology: Theory, Applications, Pitfalls and New Perspectives Edited by: H Shintani, A Sakudo (2016) www.caister.com/gasplasma

- Virus Evolution: Current Research and Future Directions Edited by: SC Weaver, M Denison, M Roossinck, et al. (2016) www.caister.com/virusevol

- Arboviruses: Molecular Biology, Evolution and Control Edited by: N Vasilakis, DJ Gubler (2016) www.caister.com/arbo

- Shigella: Molecular and Cellular Biology Edited by: WD Picking, WL Picking (2016) www.caister.com/shigella

-Aquatic Biofilms: Ecology, Water Quality and Wastewater Treatment

Edited by: AM Romaní, H Guasch, MD Balaguer (2016)

www.caister.com/aquaticbiofilms

- Alphaviruses: Current Biology

Edited by: S Mahalingam, L Herrero, B Herring (2016)

www.caister.com/alpha

- Thermophilic Microorganisms

Edited by: F Li (2015)

www.caister.com/thermophile
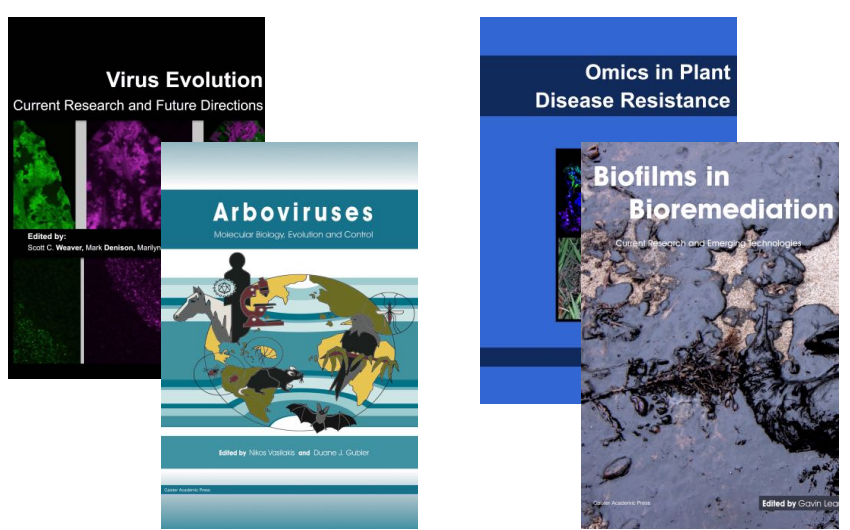
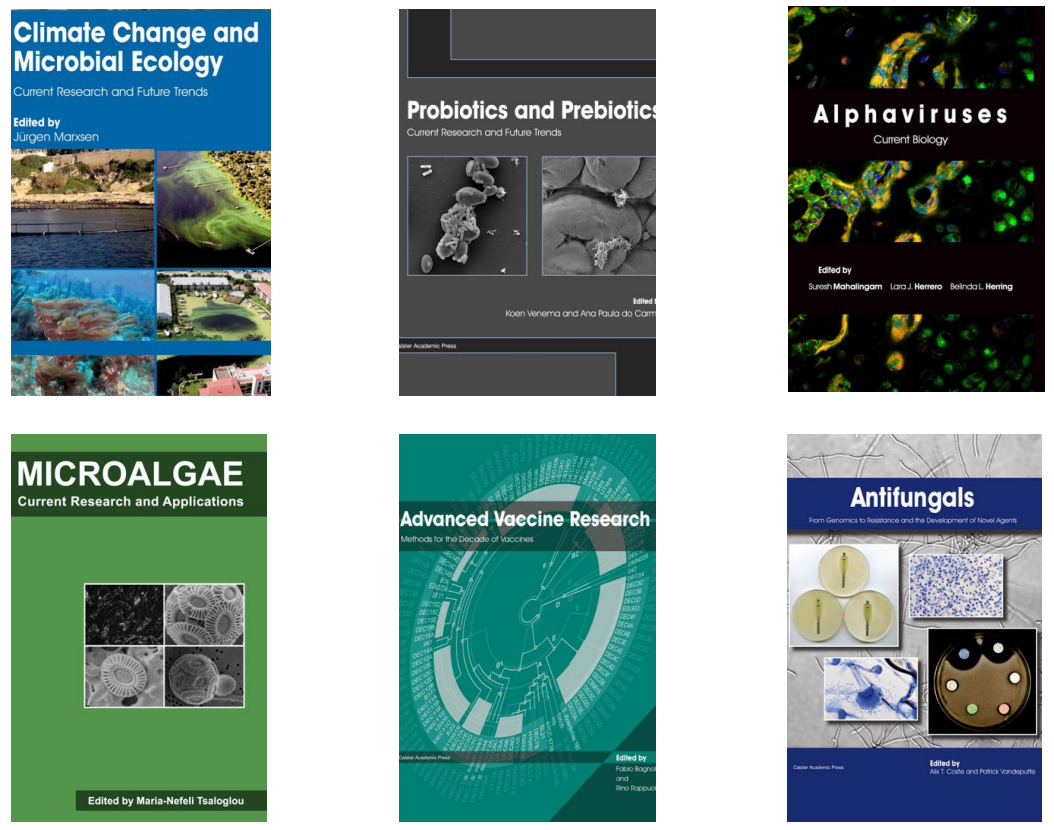

- Flow Cytometry in Microbiology: Technology and Applications Edited by: MG Wilkinson (2015) www.caister.com/flow

- Probiotics and Prebiotics: Current Research and Future Trends Edited by: K Venema, AP Carmo (2015) www.caister.com/probiotics

- Epigenetics: Current Research and Emerging Trends Edited by: BP Chadwick (2015) www.caister.com/epigenetics2015

- Corynebacterium glutamicum: From Systems Biology to Biotechnological Applications

Edited by: A Burkovski (2015)

www.caister.com/cory2

- Advanced Vaccine Research Methods for the Decade of Vaccines

Edited by: F Bagnoli, R Rappuoli (2015)

www.caister.com/vaccines

- Antifungals: From Genomics to Resistance and the Development of Novel Agents

Edited by: AT Coste, P Vandeputte (2015)

www.caister.com/antifungals

- Bacteria-Plant Interactions: Advanced Research and Future Trends Edited by: J Murillo, BA Vinatzer, RW Jackson, et al. (2015) www.caister.com/bacteria-plant

\section{- Aeromonas}

Edited by: J Graf (2015)

www.caister.com/aeromonas

- Antibiotics: Current Innovations and Future Trends

Edited by: S Sánchez, AL Demain (2015)

www.caister.com/antibiotics

- Leishmania: Current Biology and Contro Edited by: S Adak, R Datta (2015) www.caister.com/leish2

- Acanthamoeba: Biology and Pathogenesis (2nd edition) Author: NA Khan (2015)

www.caister.com/acanthamoeba2

- Microarrays: Current Technology, Innovations and Applications Edited by: Z He (2014)

www.caister.com/microarrays2

- Metagenomics of the Microbial Nitrogen Cycle: Theory, Methods and Applications

Edited by: D Marco (2014)

www.caister.com/n2 